The University of Akron

\title{
IdeaExchange@UAkron
}

Proceedings from the Document Academy

University of Akron Press Managed

January 2016

\section{Two King Lears: The Meaning Potentials of Writing and Speech for Talking Books}

Anna Hampson Lundh

Curtin University and University of Borås, anna.lundh@hb.se

Bradley Smith

Semiosmith Editing and Consulting Services, semiosmith@gmail.com

Please take a moment to share how this work helps you through this survey. Your feedback will be important as we plan further development of our repository.

Follow this and additional works at: https://ideaexchange.uakron.edu/docam

Part of the Library and Information Science Commons, and the Linguistics Commons

\section{Recommended Citation}

Lundh, Anna Hampson and Smith, Bradley (2015) "Two King Lears: The Meaning Potentials of Writing and Speech for Talking Books," Proceedings from the Document Academy: Vol. 2 : Iss. 1 , Article 6.

DOI: https://doi.org/10.35492/docam/2/1/6

Available at: https://ideaexchange.uakron.edu/docam/vol2/iss1/6

This Conference Proceeding is brought to you for free and open access by University of Akron Press Managed at IdeaExchange@UAkron, the institutional repository of The University of Akron in Akron, Ohio, USA. It has been accepted for inclusion in Proceedings from the Document Academy by an authorized administrator of

IdeaExchange@UAkron.For more information, please contact mjon@uakron.edu, uapress@uakron.edu. 


\section{INTRODUCTION}

The talking book is a type of assistive technology where original print text is audio recorded and marked-up in order to make it accessible for people with printdisabilities, such as visual impairments or dyslexia. Whereas the closely related audiobook is published for commercial purposes and targets wider audiences, the talking book is a non-commercial medium produced for print-disabled people only by governmental agencies, national libraries, and non-profit organisations.

Through its history, the talking book has been produced in various formats and been played through different types of hardware. Today, it is produced in the socalled Digital Accessible Information System (DAISY) format and can be read on, for example, computers, tablets, smartphones, mp3-players or specifically designed DAISY-players. The format includes mark-up which makes it possible to navigate in the recorded text, for example through tables of contents, headings and page numbers. Its functionality depends on the book itself (for example, whether it includes the full text version of the original or not), the type of player used, and the reader(s) ${ }^{1}$ of the book and their social environment.

There are no exact figures of how many people have print-disabilities, but there are estimates indicating that the proportion could be between five and ten percent (at least in the US, see Petri, 2012, p. 42). Little research, however, has been carried out looking at how talking books are read and how people learn to use them in their daily lives (Lundh \& Johnson, 2015). Therefore, in an ongoing research project, the documentary practices of people with print-disabilities are being explored, with a focus on their reading of talking books. Within this broad research context, in the present paper we focus on the talking book as a document and explore some of the potential implications of the conversion from a print original to the talking book form.

\section{REMEDIATION OF WRITING INTO SPEECH}

One of the most prominent differences between a print book and a talking book is the necessary inclusion of sound in the latter. The differences between the print book and a book based on sound have been discussed in an edited volume on audiobooks (note, not talking books), with regard to the aesthetic experience of fiction and poetry (Rubery, 2011). Wittkower (2011) discusses aspects of the audiobook that differ from those of a print book, for example in terms of temporality, the role of the narrator, and relationship between the reader and their

\footnotetext{
${ }^{1}$ In this text, we differentiate between readers, meaning the users of talking books, and narrators, meaning the voice(s) in the recording of a talking book.
} 
environment, highlighting the implications for the reading experience of conversion from print text to sound.

The main argument of the present paper is that the materiality of talking books does matter for the documentary practices of talking book users (cf. Frohmann, $2004 \mathrm{a} ; 2004 \mathrm{~b}$ ). Hence, we challenge the view of a book - be it a print book or a talking book - as a container of pre-existing information, which is simply unpacked when read. Instead, we draw of the work of Francke (2008, p. 125), who problematises the treatment of the conversion from one media format to another as:

[...] a simple matter of transference, in which the new medium supposedly gives access to the same epistemic content as the old medium, often with the same cognitive and sensorial experience as a result. (Francke, 2008, p. 125).

Employing the terminology of Francke (2008, pp. 12-14), the talking book can be described as a type of medium that is used for the presentation of documents that include speech as a mode of communication. These documents are always based on a print original, which means that talking books remediate (Francke, 2008, pp. 14, see also Bolter and Grusin, 2000) print books. The talking book can thus, in one sense, be seen as having compensatory functions (Lundh, 2013, pp. 34-36), as it is designed to mimic a print original that is not accessible for talking book readers.

However, the spoken, talking book form also brings into play meanings not represented in the orthographic script of written English. Thus, when reading aloud a text, the narrator must make decisions about, for example, where emphasis should be made or tone of voice (cf. Davies, 2014; Smith and Greaves, 2015). Such decisions will be determined not only by the narrator's interpretation of the source written text but, in the case of talking books, also by considerations such as whether the reading should be made with feeling or in a more monotonal style (cf. Getz, 2003; Lundh, 2013, p. 28).

The aim of this paper is to draw attention to some of the implications of the remediation of written text into speech in talking books. To do this, we examine two different spoken versions of a play, Shakespeare's King Lear. Through an examination of intonation choices in two recordings of a short excerpt of the play - one (Shakespeare, 2002a) produced by the Swedish Agency of Accessible Media, MTM (formerly known as TPB); the other a Naxos Audiobooks performance of the play (Shakespeare, 2002b); both in English - we address the following questions: What variation in meaning is evident in the two versions? What are the possible implications of such variation?

It should be noted that the comparisons made in the analysis are nonevaluative, thus leaving for example assessments of literary quality and a discussion of the supremacy of one format over the other aside. Of little interest is 
whether a talking book is "better" than its print original or not; the question is rather how a talking book is different in terms of its possibilities for meaningmaking, and why. We also leave aside here many other important questions, for example regarding aspects of the play itself, or the bases for narrators' interpretations. Our purpose is to problematise the idea that the conversion from text to sound can involve a neutral interpretation of the source (in this case literary) text. In the next section we present the theoretical tools employed in the analysis.

\section{THE MEANING POTENTIALS OF WRITING AND SPEECH}

The analytical approach in the present study is based on Halliday's (1978) social semiotic theory, which theorises meaning as the result of interacting choices within language systems (paradigms). For Halliday, language systems form a meaning potential: the range of options (potential for making meanings) available from which speakers or writers make choices (actual meanings) within texts ${ }^{2}$. Such choices are functional: they are motivated by, related to and thus to be analysed and understood with respect to the social context of the discourse.

However, as Halliday observes, the meaning potentials of the written and spoken forms of language are different: there are "various aspects of spoken language that have no counterpart in writing: rhythm, intonation, degrees of loudness, variation in voice quality ('tamber'), pausing, and phrasing" (Halliday, 1985 , p. 30; cf. also van Leeuwen, 1999). These "on-the-spot features of language" (Halliday, 1985, p. 32) play an often crucial role in making meanings in spoken language, particularly in face-to-face dialogue.

In the present study we focus on intonation, which is the patterned variation in pitch of the voice, caused by altering the rate of vibration of the vocal cords (cf. Halliday and Greaves, 2008), forming distinctive pitch movements, or contours, which occur at intervals in spoken discourse. Intonational systems, which have no systematic representation in written text, work together with other language choices in speech to help make - or realise, in Halliday's terms - certain types of meaning, and thus form an integral part of English grammar (Halliday and Greaves, 2008) and the meaning of English spoken texts. These systems, their

\footnotetext{
2 The term "meaning potentials" is also used by Linell (2009), but in a different sense: Linell uses it to refer to the "semantic potentialities of linguistic resources" (2009, pp. 332f). A word or an expression, according to Linell's use of the term, does not have an intrinsic and given meaning, but has meaning potentials "that are used in combination with contextual factors to prompt and give rise to situated meanings" (Linell, 2009, p. 330) - a similar concept to that of Halliday's context of situation, derived from Firth (e.g. 1957). These concepts will be explored in forthcoming studies.
} 
transcription, and the meanings they help realise will be presented with text examples in the next section.

The act of reading aloud a written text necessitates the reader making decisions about meaningful choices of intonation. Therefore, the reading of a play in particular, which is written text that purports to represent spoken dialogue, is itself a form of interpretation of that play. The meaning of the play, then, is created in the very act of reading, through the interaction between the (written and spoken) text(s), the reader(s), and the social and material context. In the following, we present an analysis that exemplifies how reading aloud a print text involves the potential for variation in meaning.

\section{TWO READINGS OF AN EXCERPT}

\section{ANALYTICAL FRAMEWORK}

In order to explore the issue of variation in readings of a written text, we selected an excerpt from the two recorded versions of King Lear mentioned above (Talking Book, and Audio Book, hereafter 'TB' and 'AB'). The sound files from these two excerpts were imported into Praat software (http://www.fon.hum.uva.nl/praat/), which offers a platform for close, detailed annotation of sound documents. These two excerpts were analysed for their intonation choices, with annotations performed using Halliday's intonation description and transcription system (cf. Halliday and Greaves, 2008), shown in Table 1. One difficulty with communicating through writing about intonation is that the reader here cannot actually hear the sounds to which these transcription conventions refer. We suggest, therefore, that the reader correlate the written text and symbols in the example column of Table 1 with the spoken version of these excerpts, from the $A B$ version, which can be heard via the link provided in Shakespeare (2002b). 


\begin{tabular}{|c|c|c|}
\hline System & $\begin{array}{l}\text { Transcript } \\
\text { ion symbol }\end{array}$ & Example \\
\hline $\begin{array}{l}\text { Tonicity - } \\
\text { location of pitch contour, } \\
\text { indicated by */ italics, resulting } \\
\text { in emphasis on word following } \\
\text { */ (note: double emphasis for } \\
\text { compound focus) }\end{array}$ & */ italics & $\begin{array}{l}\text { is not this your } * / \text { son my lord } \\
\text { it } * / \text { did always seem so to } * / \text { us }\end{array}$ \\
\hline $\begin{array}{l}\text { Tonality - division into tone } \\
\text { groups, indicated by // ...// }\end{array}$ & // words // & $\begin{array}{l}\text { // I thought the king had more } \\
\text { affected the Duke of */ Albany } \\
\text { than // */ Cornwall // }\end{array}$ \\
\hline $\begin{array}{l}\text { Tone - } \\
\text { Falling pitch contour } \\
\text { Rising pitch contour } \\
\text { Level pitch contour } \\
\text { Falling-rising pitch contour } \\
\text { Rising-falling pitch contour } \\
\text { Falling+level } \\
\text { Rising-falling+level } \\
\text { Secondary variations: } \\
\text { e.g. sharp fall-rise contour }\end{array}$ & $\begin{array}{l}1 \\
2 \\
3 \\
4 \\
5 \\
13 \\
53 \\
\end{array}$ & $\begin{array}{l}\text { //1 I cannot con- */ ceive you // } \\
\text { //2 is not this your */ son my lord } \\
\text { // } \\
\text { //3 there was good sport at his */ } \\
\text { making // } \\
\text { //4 I have so often blushed to ac- } \\
* / \text { knowledge him that... // } \\
/ / 5 \text { oh */ sir // } \\
/ / 13 \text { it */ did always seem so to */ } \\
\text { us // } \\
/ / 2 \_\wedge \text { this / young / fellow's } * / \\
\text { mother could // }\end{array}$ \\
\hline $\begin{array}{l}\text { Salience }- \\
\text { the first syllable after / or // is } \\
\text { accented; except where } \\
\text { indicates an unaccented first } \\
\text { syllable (e.g. where there is a } \\
\text { pause in the rhythm, or where } \\
\text { an utterance begins with an } \\
\text { unaccented syllable) }\end{array}$ & $\begin{array}{l}/ / \text { words / } \\
\text { words // } \\
/ / \wedge \text { words / } \\
\text { words // }\end{array}$ & $\begin{array}{l}/ / 2 \text { is not / this your } * / \text { son } \mathrm{my} / \\
\text { lord // } \\
/ / 1^{\wedge} \mathrm{I} / \text { cannot con- } * / \text { ceive you } / /\end{array}$ \\
\hline
\end{tabular}

Table 1: English intonation systems and their transcription

The system of tonicity is realised through the location of a pitch contour on a particular syllable, thus emphasising that word as a point of focus in a spoken text (there is also a compound focus, see below). Such points of focus break up continuous speech into separate tone groups, in the system of tonality, which thus varies the rate of occurrence of such emphasis, creating the effect of zooming in or out at particular points in a text. Particular words are also accented (given salience salient) via some form of emphasis other than that made by a pitch 
contour: e.g. lengthening of a syllable, disturbance in an established rhythm, jump up or down in pitch, loudness. These systems, called textual systems, enable speakers to organise meanings into coherent text that is relevant to some social context.

Tone choices (types of pitch contour - rising, falling, falling-rising, risingfalling, and level) work together with other language choices to realise interpersonal meanings, such as reservation or surprise, by which speakers present their stance and negotiate social roles and relations. However, in certain contexts, two tone contour types (the falling-rising, and the level contours) may function to make logical meanings, of coordination (tone 3 ) and subordination (tone 4). There are also two compound tones, the falling+level and rising-falling+level tones, where these two contours function in effect as a single, compound choice. These compound tones thus also form a configuration of major+minor (compound) focus. There are also many secondary variations for each tone choice: e.g. for the rising tone (2), a sharp fall-rise contour (2_).

\section{ANALYSIS}

We analysed the play's text from the beginning of Act I, Scene I until the entrance of King Lear ('the King is coming'). This scene starts with the Earls of Kent and Gloucester discussing King Lear's preferences for dividing his kingdom among heirs; and then Gloucester, at Kent's prompting, (somewhat shamefacedly) introduces his illegitimate son, Edmund, to Kent, with a brief but suggestive account of his conception. The purpose of the present analysis and discussion is to illustrate and explore the variation in intonation choices between different readings of the same written text, the variations in meaning that result from such choices, and the implications of such variation for the study and practice of talking books. Constraints of space limit the presentation of the full excerpt or its analysis, although the discussion below makes reference to this whole excerpt.

To start with, we focus on the question by Kent to Gloucester in Table 2:

\begin{tabular}{|l|l|l|}
\hline Speaker & TB & AB \\
\hline KENT & $\begin{array}{l}/ / 2 \text { is not / this your } * / / \\
\text { son my / lord? // }\end{array}$ & $\begin{array}{l}/ / 2 \text { is not / this your } * / \\
\text { son my / lord? // }\end{array}$ \\
\hline
\end{tabular}

Table 2: Excerpt 1.

This particular line of the play is spoken with exactly the same intonation choices in each version, $\mathrm{TB}$ and $\mathrm{AB}$. A single tone group, it has a rising pitch contour (tone 2) located on the word 'son'; while the words 'is', 'this', 'son' and 
'lord' are accented. However, for Gloucester's reply (in Table 3) the two versions are delivered with significantly different choices of intonation:

\begin{tabular}{|c|c|c|}
\hline Speaker & TB & $\mathbf{A B}$ \\
\hline GLOUCESTER & $\begin{array}{l}/ / 1^{\wedge} \text { his / breeding sir hath / } \\
\text { been at my } * / \text { charge } / / 1^{\wedge} \mathrm{I} / \\
\text { have so often / blushed to } \\
\text { ack- } * / \text { knowledge him that } \\
/ / 1 \text { now I am } * / \text { braised to it } \\
/ /\end{array}$ & $\begin{array}{l}/ / 13^{\wedge} \text { his } * / \text { breeding } * / \text { sir } \\
\text { hath //2 been at my */ charge } \\
/ / 4 \wedge \text { I have / so often / } \\
\text { blushed to ac- */ knowledge } \\
\text { him that //4*/ now //5 I am } \\
* / \text { braised to it // }\end{array}$ \\
\hline
\end{tabular}

Table 3: Excerpt 2.

In the TB version, Gloucester's reply is distributed into 3 tone groups; in the $\mathrm{AB}$ version, 5 tone groups; with variation in the location of boundaries for the tone groups, depending mainly on which words are made points of focus. In the TB version, focus is assigned to 'charge', while 'breeding' is accented and 'sir' is not accented; in AB, however, 'breeding' is emphasised as a point of focus with 'sir' as an additional minor focus (as part of the compound tone 13), while 'charge' is also made a point of focus. Both versions have 'acknowledge' as focus; but where the next item focussed on in TB is 'braised', $\mathrm{AB}$ assigns focus to both 'now' and 'braised'. There is also variation in tone choices between the two versions. $\mathrm{AB}$ has an additional tone choice, the compound tone 13 on 'breeding' and 'sir'; and whereas TB has the falling tone 1 on 'charge', $\mathrm{AB}$ has the rising tone 2 on the same word. Thereafter, TB has a sequence of tones 1 and 1; whereas $\mathrm{AB}$ has 4, 4 and 5.

Kent's response to this line, and Gloucester's subsequent reply, in Table 4, also show both similarity and difference in intonation choices.

\begin{tabular}{|c|c|c|}
\hline Speaker & TB & $\mathbf{A B}$ \\
\hline KENT & $\begin{array}{l}/ / 1^{\wedge} \mathrm{I} / \text { cannot con- } * / \text { ceive } \\
\text { you // }\end{array}$ & $\begin{array}{l}/ / 1^{\wedge} \mathrm{I} / \text { cannot con- } * / \text { ceive } \\
\text { you // }\end{array}$ \\
\hline GLOUCESTER & $\begin{array}{l}\text { //1 sir / this young */fellow's } \\
\text { mother //1 */ could //4 } \\
\text { whereupon she grew / round } \\
* / \text { wombed and //1 had in- */ } \\
\text { deed sir a //1 son of her */ } \\
\text { cradle //1 ere she had a / } \\
\text { husband for her } * / \text { bed // }\end{array}$ & $\begin{array}{l}/ / 5 \text { oh } * / \text { sir } / / 2_{-} \wedge \text { this / } \\
\text { young / fellow's } * / \text { mother } \\
\text { could //4 whereupon she / } \\
\text { grew / round } * / \text { wombed } / / 3 \wedge \\
\text { and had in- } * / \text { deed sir a } / / 4 \\
\text { son for her } * / \text { cradle //1 ere } \\
\text { she had a } * / \text { husband for her } \\
/ / 1 * / \text { bed // }\end{array}$ \\
\hline
\end{tabular}

Table 4: Excerpt 3. 
Kent's comment is intonationally identical in both versions; but there is significant variation in the interpretation into speech of Gloucester's reply. The locations of focus in each is different: in TB, 'fellow's', 'could', 'wombed', 'indeed', 'cradle' and 'bed'; in AB, 'sir', 'mother', 'wombed', 'indeed', 'cradle', 'husband' and 'bed'. There is also variation in tone choices: in TB the tones are 1, $1,4,1,1$ and 1; in AB, 5, 2_, 4, 3, 4, 1 and 1. And there are interesting variations in salience, for example: whereas in TB 'this' is accented, in AB 'this' is unaccented, the accent falling instead upon the following word 'young'; 'could' is focus in $\mathrm{TB}$, but it is unaccented in $\mathrm{AB}$.

In general, through the excerpt we analysed, there are parts of the text that do receive similar or the same treatment: as with Kent's question 'Is not this your son my lord?' and Kent's response, 'I cannot conceive you', which are treated identically in the two versions; or 'whereupon she grew round wombed', which is different only in one choice of salience, with 'grew' accented in AB but not in TB. But there are also many variations in intonation choices between the two texts, as are evident in these short examples. In the next section we will present a discussion of the meanings of some of these choices, and discuss the implications of the variation in meaning between the two versions.

\section{Two KING LEARS}

The variation in intonation choices shown above results in different meanings in the two readings, as they interact with each other and with other language choices. For example, for Gloucester's line - 'sir this young fellow's mother could' - both the $\mathrm{TB}$ and $\mathrm{AB}$ versions have two tone groups, which is a marked choice of tonality. That is, for each system there is a default, unmarked choice, and a range of other marked choices. For tonality, the unmarked choice is one tone group for each clause; all other ways of breaking up the text into tone groups are marked. In reading a written text, unless one can interpret some reason for another choice (e.g. its cohesive properties, cf. Davies 2014), the default unmarked choice only can be assumed; therefore, any departure from the default is significant. However, although both versions are similar in that they break up this line into two tone groups, the boundaries of the tone groups and the points of focus are quite different, resulting in two very different interpretations of this line.

In $\mathrm{TB}$, the division is after 'mother', thus making 'could' a separate tone group and point of focus; but the focus in the first tone group is on the word 'fellow', not 'mother'. This is also a marked choice: the default choice of focus is the final lexical (content) word in a tone group, which in this case would have been 'mother'. This combination of tonality and tonicity choices can perhaps best be understood by contrast with that of the $\mathrm{AB}$ text. In $\mathrm{AB}$, 'sir' is given its own separate tone group and is a point of focus (as well as having the exclamative 'oh' 
added before it). This focus on 'sir', a term of address, highlights the dialogic, interpersonal aspect of the text. In addition, while the TB reading has 'fellow' as focus, the $\mathrm{AB}$ reading has 'mother' as focus, the latter choice setting up a contrastive relationship of cohesion with 'I' in Kent's line. These choices together result in a clear sense of innuendo in the $\mathrm{AB}$ text, highlighting the double entendre involved in the two senses of the word 'conceive' (to understand; and to become pregnant): i.e. the meaning is, you (Kent) cannot conceive (understand) me, but this young fellow's mother could conceive (i.e. become pregnant by) me.

This meaning of innuendo is further realised through tone choices. The TB text has two tone $1 \mathrm{~s}$. The falling tone is the default or unmarked choice for a statement (just as the rising tone is the unmarked choice for a yes/no question, as in 'is not this your son my lord?'); thus, in terms of tone, the TB makes two unmarked (and thus unremarkable) choices for this statement. The AB version, however, makes two marked choices of tone, in a very different interpretation of the play script. The AB text gives 'sir' a rising-falling tone, tone 5 being the common choice for exclamations (e.g. 'wow!'). This adds interpersonal force to the highlighting of 'sir' provided by the marked tonality and tonicity choices. In the next tone group, the $\mathrm{AB}$ text uses a secondary variant of the rising tone 2, the sharp falling-rising tone 2_ (often found when someone incredulously repeats a provocative statement, as in 'you believe the Earth is flat?!'), which creates a heightened sense of interpersonal challenge to the contrastive focus on the word 'mother' discussed earlier.

The tone of innuendo and the heightened interpersonal energy of the $A B$ text is absent in the TB version. The TB reading does have marked choices of tonality and tonicity, but these seem to be less about specific choices of focus (such as the contrastive focus on 'mother' in $\mathrm{AB}$ ) and more about adding emphases for the purpose of clarity in reading. (However, the choice of 'fellow' rather than 'mother' in the TB text might imply an avoidance of focus on 'mother' with its attendant sense of innuendo).

This is a pattern found throughout the excerpt analysed for this study (from the beginning of the play down to King Lear's entrance). In general TB does add extra textual focus through marked tonality and, in places, marked tonicity choices: for example TB has two tone groups for the following, //1 $\wedge /$ some year */ older than //1 */ this //; while AB has one, //1_ some / year */ older than / this //. However, these seem more to do with the need for a very clear reading style, rather than adding any particular textual meaning through some specific point of focus. The result is a somewhat more formalised tone, such as one finds in news reading (see van Leeuwen, 1992 for a discussion).

When one finds marked choices in the AB text, however, these appear motivated by some particular interpretation of the meaning of the source text (the play script itself): for example also, where 'husband' is made a point of focus, 
again drawing attention to the fact of Gloucester's son being conceived out of wedlock. There are instances where it is the TB text that has marked tone choices, as in the following, //5 $\wedge$ who / yet is / no */ dearer in //1 my ac- */ -count //, which has a tone 5 adding a sense of interpersonal commitment to the first part of this line, absent in $\mathrm{AB}, / / 1^{\wedge}$ who / yet is no / dearer in / my ac- */ -count //. Overall, however, the choices in the TB text point to an attempt to depersonalise while making accessible the play text to the talking book reader. This way of reading the play is quite distinct from that of the $A B$ version, where the narration infuses the play script with all the variety and colour of spoken dialogue, the interpersonal and textual meanings realised by intonation systems, providing a greater richness of characterisation. One could say that, overall, the TB narrator reads the play, whereas the $\mathrm{AB}$ narrator acts the play.

The first thing to note in this short analysis is that there is variation, in choices from intonation systems and the meanings they help make, between the two versions of this excerpt from King Lear. There are, as a result of such variation, not one but two King Lears; each, to some extent at least, an invention of the narrator. In the concluding section, the potential implications of this variation are addressed.

\section{THE POTENTIAL IMPLICATIONS OF REMEDIATION}

The above analysis provides support against the naive view of remediation - in this case from written to spoken language - as a simple process of transfer from one format to another. The spoken play is not simply a sounding version of the written play; rather, the spoken version opens up the potential for many different meanings in different readings of the play. While we have here examined intonation choices only, there are many other features of speech, such as those mentioned in the Halliday (1985, p. 30) quote earlier (e.g. voice quality, loudness), which similarly provide the potential for meaningful variation in readings of a play or any other written text (cf. van Leeuwen, 1999). Such a claim has, of course, important implications for readings of all written texts, particularly those that purport to represent spoken dialogue (for example, transcripts of legal or political discourse), where intonation makes such a crucial contribution (cf. Halliday and Greaves, 2008).

That intonation does matter for the talking book reading experience has been discussed previously (Getz, 2003; Lundh, 2013, p. 28), but without arriving at consensus on whether talking books readers prefer reading with feeling or more monotone readings. The question is important, however, not least because of the increased possibilities for using synthesised (often monotonal) speech in the

production of talking books. One implication of variation in intonation could be that different styles of narration require different ways of reading. For example, it 
might be that a recording with a high degree of intonational variation is helpful for the beginner talking book reader, as much of the interpretive work is done by the narrator(s). Accordingly, a recording with a lower degree of intonational variation might leave more room for the readers' own interpretive work. In addition, the sort of careful division into tone groups and lack of tonal variation identified in the above TB analysis might translate into a better reading experience for those talking book readers who prefer their reading recordings to be played at higher speeds.

These considerations point to the need to explore how intonation makes meaning for actual talking book readers in situ; as well as how narrators bring their own understandings of plays and other written texts to their reading. In future studies, we will further explore how meaning potentials are realised through interactions and encounters between the source written text, the reader(s), the social settings in which they are reading, and the technology and the material properties of talking books.

\section{REFERENCES}

Bolter, J.D. and Grusin, R. (2000), Remediation: understanding new media, (Paperback ed.), MIT Press, Cambridge, MA.

Davies, M. (2014), The black hole in graphology, In Bowcher, W.L. and Smith, B.A. (Eds.), Systemic phonology: recent studies in English, Equinox, London, pp. 153-198.

Firth, J.R. (1957), Papers in linguistics: 1934 - 1951, Oxford University Press, London.

Francke, H. (2008), (Re)creations of scholarly journals: document and information architecture in open access journals, Valfrid, Borås, Diss.

Frohmann, B.P. (2004a), Deflating information: from science studies to documentation, University of Toronto Press, Toronto.

- (2004b), Documentation redux: prolegomenon to (another) philosophy of information, Library Trends, Vol. 52, No. 3, pp. 387-407.

Getz, I. (2003), What do blind people want from talking books?, The 69th IFLA General Conference and Council, August 1-9, Berlin, available at http://webdoc.sub.gwdg.de/ebook/aw/2003/ifla/vortraege/iv/ifla69/papers/074e -Getz.pdf

Halliday, M.A.K. (1978), Language as social semiotic, Edward Arnold, London.

- (1985), Spoken and written language, Deakin University Press, Waurn Ponds, Victoria.

Halliday, M.A.K. and Greaves, W. S. (2008), Intonation in the grammar of English, Equinox, London. 
Linell, P. (2009), Rethinking language, mind, and world dialogically: interactional and contextual theories of human sense-making, Information Age Publ., Charlotte, NC.

Lundh, A.H. (2013), Talking books and reading children: children describing their use of talking books, Swedish Agency for Accessible Media, Johanneshov.

Lundh, A.H. and Johnson, G.M. (2015), The use of digital talking books by people with print disabilities: a literature review, Library Hi Tech, Vol 34, No 1 , pp. $54-64$.

Petri, K. (2012), Accessibility issues in E-books and E-book readers, In Polanka, S. (Ed.), No shelf required 2: use and management of electronic books, American Library Association, Chicago, pp. 35-60.

Rubery, M. (Ed.) (2011), Audiobooks, literature, and sound studies, Routledge, New York.

Shakespeare, W. (2002a), King Lear, TPB, Enskede.

- (2002b), King Lear, Naxos Audiobooks, Redhill, Surrey, Excerpt available online at http://www.naxosaudiobooks.com/324412.htm

Smith, B.A and Greaves, W.S. (2015), Intonation. In Webster, J.J. (Ed.), The Bloomsbury companion to M.A.K. Halliday, Bloomsbury, London, pp. 291313.

van Leeuwen, T. (1992), Rhythm and social context: accent and juncture in the speech of professional radio announcers, In Tench, P. (Ed.), Studies in systemic phonology, Pinter Publishers, London; New York, pp- 231-262.

- (1999), Speech, music, sound, MacMillan Press, Hampshire; London; St. Martin's Press, New York.

Wittkower, D. (2011), A provisional phenomenology of the audiobook, In Rubery, M (Ed.), Audiobooks, literature, and sound studies, Routledge, New York, pp. 216-231. 